\title{
動物細胞における糖輸送の調節
}

\author{
山田一夫 \\ 広島大学医学部生化学第一教室 $\mathbf{7} 734$ 広島市南区霞 1-2-3 \\ 国立生理学研究所能動輸送部門 $\mathbf{T} 444$ 岡崎市明大寺町字西郷中 38
}

\section{Regulation of hexose transport in animal cells}

\begin{abstract}
Kazuo Y AMADA
Department of Biochemistry, Hiroshima University, School of Medicine, Hiroshima 734

Laboratry of Active Transport, National Institute for Physiological Sciences, Myodaiji, Okazaki 444

Simple diffusion, sodium-dependent (active) and-independent (facilitated) transports are generally involved in hexose transport in animal cells. The regulation of facilitated hexose transport has been briefly reviewed. Hexose transport regulation is observed in most cells where the rate of hexose transfer is rate limiting for hexose metabolism. Experimental methods used for assay of transport activities and indentification of glucose carrier are very important to deduce any definitive conclusion regarding the regulation of glucose transport. Possible mechanisms of transport regulation might involve 1) control of the carrier synthesis and/or turn over 2) recycling of the carrier 3) modification of the carrier 4) interaction between the carrier and its lipid environment.
\end{abstract}

key words : Hexose transport, Regulation, Hexose carrier, Protein synthesis, Membrane lipid

1 はじめに

2 糖輸送調節機構の解析

2 - 1 輸送活性の测定

$2 \cdot 2$ 分離, 同定, 精製

3 糖輸送調節機構

$3 ・ 1$ タンパク質合成系を介する機構

$3 \cdot 2$ 糖輸送担体のリサイクリングによる調節

$3 \cdot 3$ 糖輸送担体の修飾（活性化、不活性化） による調節

$3 ・ 4$ 細胞膜の脂質組成変化による調節

4 おわりに

\section{1. はじめに}

細胞膜は外界と隔てる障壁を形成することにより, 細 胞独自の内部環境を形成させる機能を有する. 細胞膜は リン脂質分子の二重層より成り, イオン $\left(\mathrm{Na}^{+}, \mathrm{K}^{+}\right.$,
$\mathrm{Ca}^{2+}, \mathrm{Cl}^{-}$など), 低分子化合物（糖, アミノ酸, 核酸 なよ゙）に対して不透過である.したがって, 細胞が代謝 活動を営むためには, 外部から栄養物を取り込む機構を 持つ必要があり, 細胞膜はそれぞれ特定の物質を特異的 に輸送する機能が存在する. このように選択的に物質を 速やかに透過させる機構として, 担体(キャリア) やチャ ンネルと呼ばれる特異的な膜タンパク質が存在する.

動物細胞における糖輸送系は, エネルギーを必要とせ ず, 細胞内外の糖濃度差によって輸送される促進拡散 (facilitated diffusion) と細胞外 $\mathrm{Na}^{+}$濃度に依存した エネルギー共役による濃度勾配に反した能動輸送とが存 在する. 両者ともに, 細胞膜に存在する特異的な輸送担 体タンパク質 (carrier protein)によって媒介される. 前者は線維芽細胞, 脂肪細胞, 赤血球, 骨格筋細胞など 多くの細胞に存在し1, 2), 後者は小腸上皮細胞, 尿細管 上皮細胞の刷子縁膜にみられる ${ }^{3 \sim 5)}$.

生体における糖代謝の最も重要な意義は, エネルギー 
産生にある.この糖代謝の第一段階は, 糖の細胞外から 内への細胞膜透過過程であり, 糖代謝の重要な調節段階 の一つである. したがって, 細胞は細胞自身の状態 (増 殖速度, 成長, 分化, 腫瘍化など) や細胞外の環境（細 胞外糖濃度, ホルモン, 成長因子, $\mathrm{pH}$, イオンなど）に 応じて糖輸送活性を変化させることにより動的に調節し ている6).

本稿では促進拡散による糖輸送系の調節機構につい て，筆者らの成績と最近の知見を述べる.

\section{2. 糖輸送調節機構の解析}

\section{2 - 1 輸送活性の測定}

糖輸送調節機構の解析には，一般的に遊離細胞， ある いは組織培養細胞が用いられる.この実験系では細胞自 身の状態, 外部環境を容易に変化させることができる.

調節機構を解析するためには，まず輸送活性の变化を 実験系に応じて正確に測定する必要がある. 生細胞を用 いる実験系では，糖輸送に対する細胞内代謝の影響を除 くため, 非代謝糖である 3-0-メチルグルコース (3-OMG) または 2-デオキシグルコース (2-DOG) が輸送基質と して用いられる7゙。しかしながら，3-OMG を用いた場 合, その取り込みが短時間 (秒単位)でほぼ飽和点に達 するため正確なキネティクスを得るのに工夫が必要であ ることと, D-グルコースに比べ輸送担体を介さないと思 われる3-OMG の取り込み量 (単純拡散+吸着) が無視 できない值を示す場合があることである ${ }^{8,9)}$. 一方, 2-DOG を用いた場合，この基質が細胞内でリン酸化を 受けることにより, リン酸化活性を測定しているのか, 真の糖輸送活性を測定しているのかを検討する必要があ $3^{10)}$.

このような問題点を解決するため, 細胞質成分を除 去して輸送活性の変化を細胞膜の変化として確かめ得 る膜小胞 (membrane vesicle) が輸送解析に用いられ る $^{11}{ }^{12)}$. さらに, 可溶化した輸送担体を含む膜タンパ ク質を人工膜 (liposome) に組み込み, 輸送活性を測定 する再構成法も用いられる ${ }^{13.14)}$.

サイトカラシン B (cyt B) は糖輸送担体と特異的に 結合して輸送活性を非拮抗的に阻害する.この結合は高 濃度の糖輸送系の基質および輸送阻害剂により阻害され る.この性質を利用し, D-グルコース感受性 $\left[{ }^{3} \mathrm{H}\right]$-cyt B 結合活性により糖輸送担体の量を測定し, 糖輸送活性の 変化を検討することが行われる15.16) (Fig. 1).

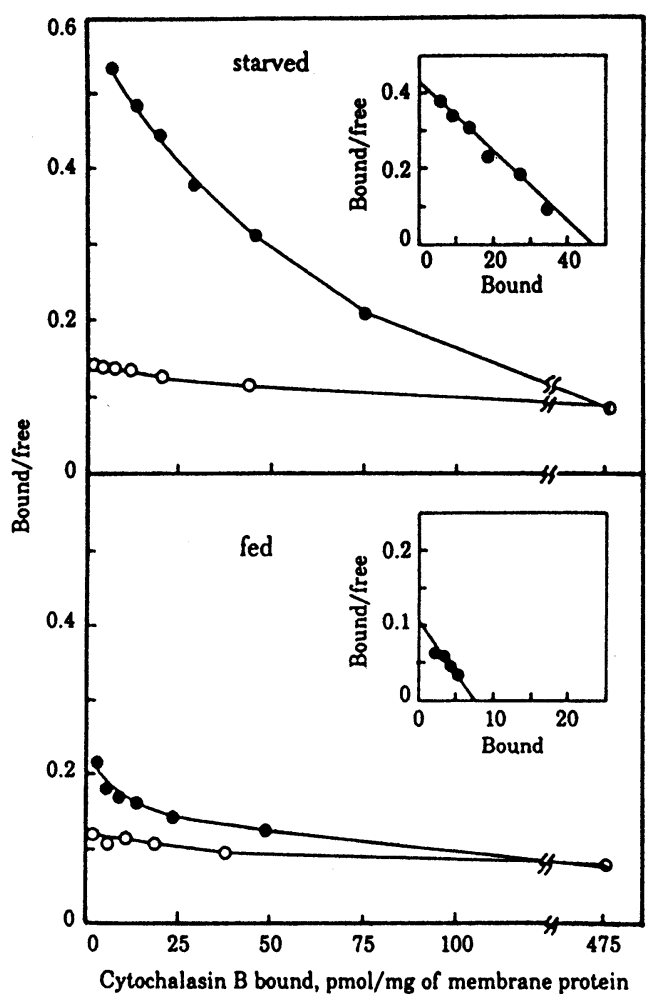

Fig. 1 ニワトリ胎児線維芽細胞膜小胞の $\left[{ }^{3} \mathrm{H}\right]$ サイト カラシンB結合能に対する Scatchard plot ${ }^{16)}$. 挿入図はグルコース感受性結合能をプロット

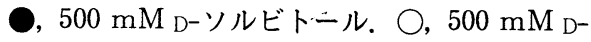
グルコース

\section{$2 \cdot 2$ 分離, 同定, 精製}

すべての輸送系において, その輸送担体の合成と分解 との平衡状態でその輸送活性は規定される. さらに輸送 担体そのものの修飾（活性化, 不活性化）によっても活 性は変化し得る.したがって, 糖輸送担体を分離, 同定, 精製し, 糖輸送担体の代謝回転, 分子構造上の変化を明 らかにする必要がある.

\section{$2 \cdot 2 \cdot 1$ 膜の修飾法}

細胞膜小胞をアルカリ低張液, トリプシン, 無水ジメ チルマレイン酸 (DMMA) などの処理により, ある程 度膜タンパク質を除去したのち, 膜小胞の糖輸送活性と 残存タンパク質との関係を検討し, 輸送担体を同定する 方法である ${ }^{17) . ~}$

この修飾方法では完全に担体を同定することは不可能 である. 


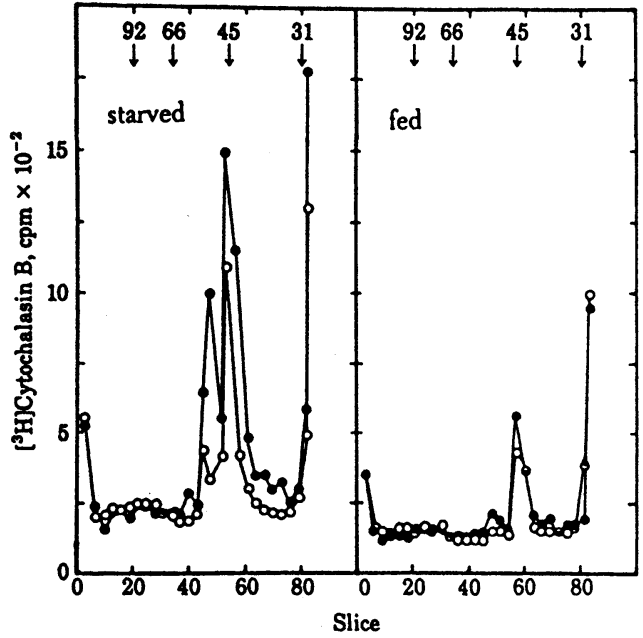

Fig. 2 ニワトリ胎児線維芽細胞膜小胞の ${ }^{3} \mathrm{H}$ サイトカ ラシンBフォトアフィニティラベル16).

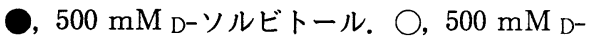
グルコース

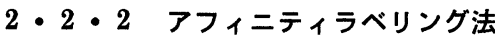

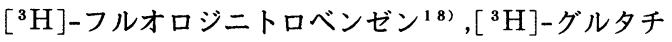
オンマレイミド19) を糖輸送担体と共有結合させ測定す る方法である. その特異性については, 前者の場合, そ の結合能が D-グルコース，2-DOG により促進されるこ と,また前者, 後者とも糖輸送系の阻害剂である cyt B，工 チリデングルコース, D-マルトースにより阻害されるこ とによるものである.

さらに前述したように, cyt B は糖輸送担体に特異的 に結合するが, 最近, この cyt B の結合が紫外線照射 により共有結合に変化することが示された ${ }^{20.211}$ 。これ らの点を利用して $\left[{ }^{3} \mathrm{H}\right]$-cyt B のフォトアフィニティ ラベル法が用いられる(6) (Fig. 2). 同様なフォトア フィニティラベル法として, $\left[{ }^{3} \mathrm{H}\right]$-マルトシルイソチオ シアナート 22) も用いられているがその特異性について は疑問がもたれている ${ }^{23)}$. その他, [ $\left.{ }^{125} \mathrm{I}\right]-6-\mathrm{N}-(4-ア$ ジド-2-ヒドロキシ-3, 5-ジヨードベンゾイル)-D-グル

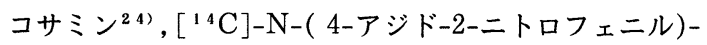
マルトシルアミン ${ }^{25)}$ や $\left[{ }^{3} \mathrm{H}\right]-$ ホルスコリン ${ }^{26)}$ を用い た方法も報告されている.

\section{$2 \cdot 2 \cdot 3$ 再構成法}

可溶化した膜タンパク質, 精製した膜タンパク質をリ ン脂質の人工膜に組み込み輸送活性を測定する方法であ $\Xi^{13)}$ 。この再構成法は，精製した膜タンパク質による
膜 (MEMBRANE), Vol.12 No.6 (1987)

315

糖輸送活性を直接測定できる唯一の方法であり, 輸送担 体の同定には最も重要な方法である.

\section{2・2・4 抗体法}

精製したヒト赤血球糖輸送担体に対する抗体を調製 し, 免疫学的手法により輸送担体を同定, 定量すること が行われる27,28). それは種々の細胞の促進拡散による 糖輸送担体とヒ卜赤血球糖輸送担体とに共通性が認めら れ，抗体の交叉性が認められることによる ${ }^{29)}$.しかし, $\mathrm{Na}^{+}$依存性能動輸送担体とは交叉性が認められていな い. 促進拡散による糖輸送担体に対するモノクロナル抗 体も報告されている30.31).

\section{3. 糖輸送調節機構}

現在, 糖輸送調節においてある程度その機構が判明し ているのは適応調節およびホルモン（インスリン）によ る調節である. 糖輸送調節機構を 4 つの様式に大別して 述べる.

\section{$3 ・ 1$ タンパク質合成系を介する調節}

このタンパク質合成系を介する調節機構にはふたつの 機構が考えられる. 1) 糖輸送担体タンパク質の合成そ のものの速度を変化させて調節する機構, 2) あるタン パク質性調節因子が存在し, そのタンパク質の合成速度 を変化させることにより, 糖輸送系が調節される機構と である.

\section{$3 ・ 1 ・ 1$ 糖輸送担体タンパク翼合成の調節}

腫瘍化に伴う糖輸送活性の上昇は, 生細胞 ${ }^{7,8.32)}$, 膜小胞 ${ }^{33.34)}$ を用いた輸送キネティクスの実験より $V_{\text {max }}$ の增大によることが認められ, 糖輸送担体の数の 増加であるとされている. 実際, cyt B 結合活性の増加 が認められ ${ }^{15)}$, さらに, ヒトの赤血球の糖輸送担体の モノクロナル抗体を使用して担体数の増加を確認した報 告 ${ }^{35)} も$ ある. 以上のように, 腫瘍化に伴い $V_{m a x}$ は増 大するが $K_{m}$ 值は有意に変化しないという報告が多い. しかし, 腫瘍細胞では正常細胞に比べ $K_{m}$ 値が低いとの 報告もある ${ }^{36,37)}$.

腫瘍化による糖輸送調節機構について, Kawai ${ }^{38)} ら$ はラウス肉腫ウィルス温度感受性変異株を感染させた二 ワトリ胎児線維芽細胞 (CEF) について検討した.すなわ ち增殖温度を非許容温度 $\left(41^{\circ} \mathrm{C}\right)$ から許容温度 $\left(37^{\circ} \mathrm{C}\right)$ へ変化させた時に起こる糖輸送活性の増加を, シクロへ キシミドおよびピュロマイシンが阻害することを示し, さらにこの逆の過程をピュロマイシンが阻害したことか ら, 腫瘍化に伴う糖輸送変化にタンパク質合成の関与が 


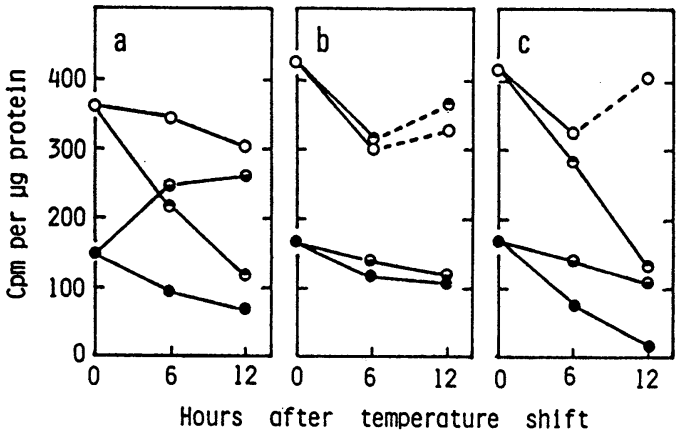

Fig. 3 Ts-68 感染細胞による 2-デオキシグルコース 取り込みに対する培養温度およびタンパク質合 成阻害剂の影響 ${ }^{38)}$.

, $37^{\circ} \mathrm{C} .0,41^{\circ} \mathrm{C} . \ominus, 37^{\circ} \mathrm{C} \rightarrow 41^{\circ} \mathrm{C}$.

○, $41^{\circ} \mathrm{C} \rightarrow 37^{\circ} \mathrm{C}$.

(a) 無処理, (b) ピュロマイシン $(2 \mu \mathrm{g} / \mathrm{ml})$ 処 理, (c) シクロヘキシミド $(2 \mu \mathrm{g} / \mathrm{ml})$ 処理

示された (Fig. 3). 最近, Flier ${ }^{39)}$ らは, 培養ラット線 維芽細胞において, ras, src 遺伝子により誘導される糖 輸送活性の上昇と, 糖輸送担体 mRNA の上昇との直 接的な相関性を, 糖輸送担体に対する $\mathrm{cDNA}$ を用いて 示した. すなわち腫瘍化による糖輸送活性の上昇は糖輸 送担体タンパク質合成の増加によることが判明した. さ らに彼らは, 腫瘍プロモーターによる糖輸送系の調節機 構（ラット線維芽細胞）は, 上述の腫瘍化と同様に糖輸 送担体タンパク質合成の増加であることを示した。

$3 ・ 1 ・ 2$ タンパク筫性調節因子による調節

増殖培地中の糖濃度により逆相関的に糖輸送活性は変 化する (適応調節) ${ }^{9,40)}$. 培地中から糖を除くと, 数時 間以内に糖輸送活性が数倍上昇する (up regulation). 逆に, 高い糖輸送活性を有する糖飢餓細胞に糖を再添加 すると糖輸送活性は低下し, 数時間以内に元のレベルに もどる事実がある (down regulation) ${ }^{9,41)}$ 。この糖輸 送活性の変化はキネティックス解析により, $K_{m}$ 值の変 化ではなく $V_{m a x}$ 值の増加または減少による ${ }^{9,42)}$.さ
らに, この $V_{\max }$ 值の変化は輸送担体の数の変化である ことが確かめられている ${ }^{16,44)}$. 糖輸送活性に及ぼす糖 飢餓効果は, タンパク質合成阻害剂であるシクロヘキシ ミド $(\mathrm{Cx})$, ピュロマイシン, エメチンなどにより阻害 される9.40,42〜44).このことは, up regulation に新 しい輸送担体の合成が関与することを意味する.しかし, 輸送活性は輸送担体タンパク質の合成と分解との平衡状 態により決定されるものであり，前述の実験結果から up regulation の機構が輸送担体の合成速度を促進する ことのみによると結論するのは早計である. 言いかえる と, 輸送担体の合成速度は一定でその分解系のみが阻害 されても同様の結果となる.

糖添加による糖輸送活性の低下過程にもタンパク質合 成系が関与する $\left.{ }^{9}, 41,43 \sim 45\right)$ 。筆者ら ${ }^{46)}$ はニワトリ胎 児線維芽細胞を用い, 糖輸送の適応調節におよぼす増殖 培地中の $\mathrm{Cx}$ 濃度の影響を調べた。 その結果, 低濃度の $\mathrm{Cx}(\mathrm{Cx}-\mathrm{L}, 0.5 \mu \mathrm{g} / \mathrm{dl})$ では合成系のみが阻害され, 高 濃度の $\mathrm{Cx}(\mathrm{Cx}-\mathrm{H}, 50 \mu \mathrm{g} / \mathrm{dl})$ では合成系，分解系共に 阻害されることが判明した (Fig. 4). 具体的には，糖飢 餓状態の細胞 $(\mathrm{S})$ の糖輸送活性は, $\mathrm{Cx}$ 濃度変化の影響 を受けないこよよりその輸送担体の代謝回転は遅いと考 えられた. すなわち飢餓状態の細胞では, 輸送担体の分 解過程はほとんど働かず，したがって高い輸送活性を示 す. 一方, 糖添加培地で培養した正常細胞では, 糖輸送 担体の代謝回転が速く，その合成之分解過程の平衡状態 によって低い輸送活性を示す．正常細胞 $(F)$ を低濃度 $\mathrm{Cx}$ 存在化で培養すると, 急速な糖輸送活性の低下が みられたが高濃度の $\mathrm{Cx}$ ではゆるやかな低下がみられ た (Fig. 5).この正常細胞から飢餓状態への変化 (up regulation) では, 輸送担体の分解過程が遅くなり, 合 成系のみ働くため輸送活性が上昇する.この合成系を Cx が阻害するため, 糖輸送活性の up regulation は $\mathrm{Cx}$ の濃度に応じて阻害された。一方, 糖飢餓状態の細 胞に糖を再添加すると, 糖輸送担体の分解過程が促進さ れる結果輸送活性は低下する.この時同時に $\mathrm{Cx}-\mathrm{L}$ を

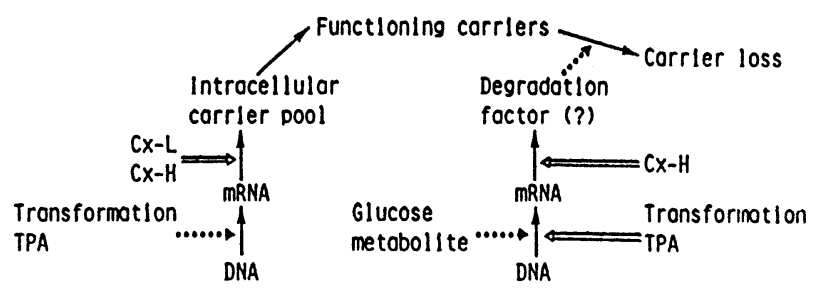

Fig. 4

ニワトリ胎児線維芽細胞における糖輸送の適応 調節および腫瘍化, 腫瘍プロモーターによる調 節機構.

s........ stimulation inhibition 

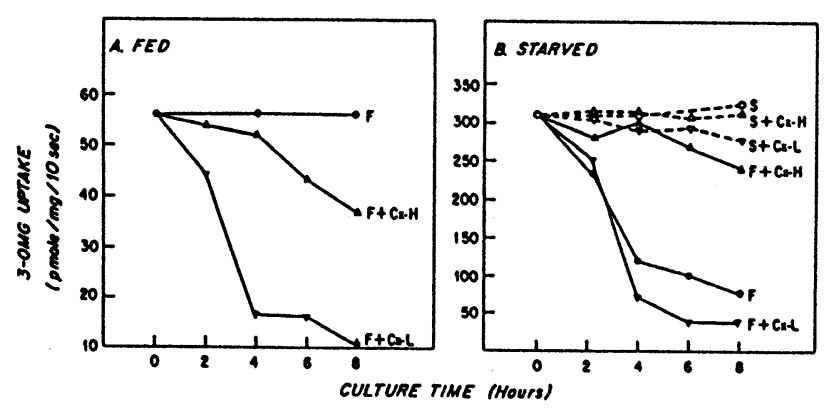

Fig. 5

ニワトリ胎児線維芽細胞の正常および糖飢餓細 胞による 3-0-メチルグルコース取り込みに対 するシクロへキシミドの影響 ${ }^{46)}$.

$\mathrm{F}$, 正常細胞、糖再添加. S, 糖飢餓状態 $\mathrm{Cx}-\mathrm{L}$, 低濃度シクロヘキシミド $(0.5 \mu \mathrm{g} / \mathrm{ml})$ $\mathrm{Cx}-\mathrm{H}$, 高濃度シクロヘキシミド $(50 \mu \mathrm{g} / \mathrm{ml})$

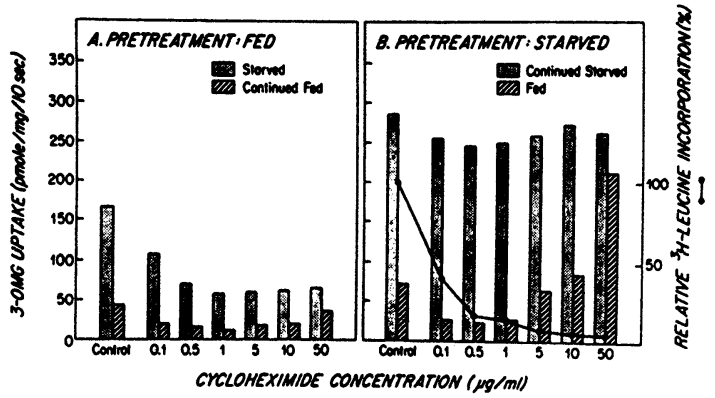

Fig. 6 ニワトリ胎児線維芽細胞による 3-0-メチルグ ルコース取り込みに対するシクロへキシミド濃 度の影響 4 6).

シクロヘキシミド処理時間は 6 時間

添加すると，この低下はさらに促進され， $\mathrm{Cx}-\mathrm{H}$ ではこ の低下は阻害されるという $\mathrm{Cx}$ 濃度変化の影響に二相性 がみられた (Fig. 6). 糖存在下（正常細胞, 糖再添加） で $\mathrm{Cx}$ 濃度変化の影響が二相性を示すのは, 低濃度 $\mathrm{Cx}$ では合成過程のみが阻害され, 高濃度 $\mathrm{Cx}$ では合成, 分 解両過程ともに阻害されるとすれば説明できる.これら の事実より, 糖輸送における適応調節は, 主に糖輸送担 体の分解過程で調節され，その過程にはタンパク質合成 系の関与が考えられた.この仮説は, 最近の Haspel ${ }^{47)}$ らのラット線維芽細胞を用いた適応調節機構を調べた結 果により支持される. 彼らは糖輸送担体に対する $\mathrm{cDNA}$ および糖輸送担体に対する抗体を用いて，糖輸送担体に 対する mRNA 量を測定したところ, 糖飢餓状態にし ても糖輸送担体の mRNA の增加はみられなかったこ と,さらに, $\left.{ }^{35} \mathrm{~S}\right]$-メチオニンによるパルスラベル法 により, 糖輸送担体の合成速度も変化がなかったことを 示した.

以上のように糖輸送の適応調節において, 輸送担体の 分解（不活性化）過程が重要な役割をしていること,こ
の過程にタンパク質合成系が関与することが判明した が，このことはある種のタンパク質性調節因子がこの分 解過程を促進させることを示唆する.

腫瘍化に伴う糖輸送能変化は糖輸送担体タンパク質の 合成の上昇によることは述べた，筆者ら ${ }^{48)}$ も Kawai らと同様の実験系を用いて, Cx の濃度変化の影響を調 べた結果, 前述の適応調節の場合 (Fig. 6) と同様, 腫 瘍化に伴う糖輸送活性の上昇は $\mathrm{Cx}$ 濃度に応じて阻害さ れた．逆に，腫瘍化した細胞の正常化に伴う糖輸送活性 の低下に対しては， $\mathrm{Cx}$ 効果の二相性が観察された．以 上の結果は, 腫瘍化に伴う糖輸送系の調節は, 輸送担体 の合成の增加と, 輸送担体の分解過程の阻害とにより調 節されている可能性を示す (Fig. 4). 腫瘍プロモーター による糖輸送の調節もある細胞では輸送担体の合成の増 加 ${ }^{39)}$ 之輸送担体の分解過程の阻害 ${ }^{49)}$ とにより調節され ていると思われる (Fig. 4).

\section{$3 ・ 2$ 糖輸送担体のリサイクリングによる調節}

生体内において糖輸送系を調節する最大因子はインス リンである．インスリンは種々の細胞の糖輸送活性を上 昇させることにより血糖値を一定のレベルに低下させ る.インスリンによる糖輸送活性の上昇は， $K_{m}$ 値に変 化がほとんよ゙認められず, $V_{\text {max }}$ 值の増加がみられたこ とより糖輸送担体の数の増加によるとされていたがその 機構は不明であった。

1978 年, Kono $ら^{50)}$, Cushman $~_{51)}^{{ }^{11}}$ は, インスリ ン作用前後における脂肪細胞の細胞膜, ミクロゾーム画 分中の糖輸送担体数の変化を測定(それぞれ再構成実験, サイトカラシンB結合実験）し，糖輸送担体のリサイク リング説 (translocation theory, recycling theory) を述べた. インスリンがその受容体に結合すると, 細胞 内プール（ミクロゾーム画分）から糖輸送担体が細胞膜 へ転移する．この過程には ATP が必要であり, タンパ ク合成系の関与はみられず，温度に依存する ${ }^{52)}$ 。その 
Table 1 ラット脂肪細胞における糖輸送担体のインスリン によるリサイクリング（文献 54 の Table 2 を改変）

\begin{tabular}{lccc}
\hline \multirow{2}{*}{ Treatment } & \multicolumn{3}{c}{ Glucose transporter } \\
\cline { 2 - 4 } & $\begin{array}{l}\text { Plasma } \\
\text { membrane }(\%)\end{array}$ & $\begin{array}{l}\text { Low density } \\
\text { microsome fr. (\%) }\end{array}$ & Total (\%) \\
\hline Basal & $21 \pm 2.0$ & $79 \pm 2.0$ & 100 \\
Insulin & $71 \pm 3.5$ & $29.9 \pm 3.5$ & $100 \pm 10$ \\
Removal of insulin & $35 \pm 2.2$ & $65 \pm 2.2$ & $92 \pm 5$ \\
Readdition of & $73 \pm 5.6$ & $27 \pm 5.6$ & - \\
insulin & & & \\
\hline
\end{tabular}

イムノブロット法により定量

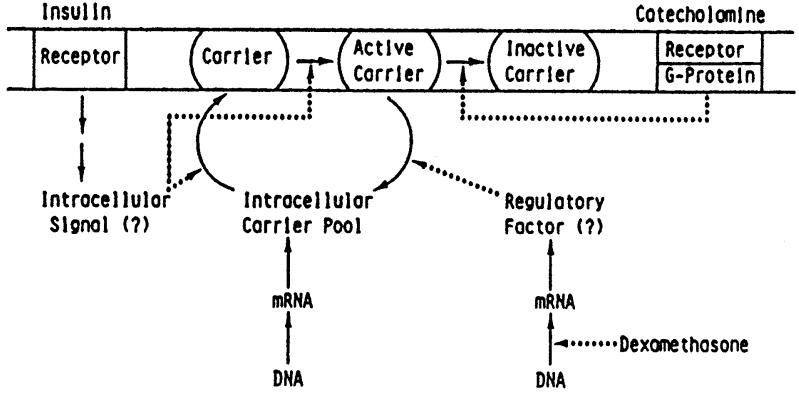

Fig. 7

ラット脂肪細胞における糖輸送のホルモンによ る調節機構
結果, 糖輸送活性は上昇すると同時に細胞内糖輸送担体 プールは減少する。この事実はインスリンによる糖輸送 活性の促進が $K_{m}$ 值の変化よりも $V_{\text {max }}$ の增加によるこ とを支持する結果である．インスリンの作用が消失する 之, 糖輸送担体が ATP 依存性に細胞内プールにもごる ことにより元のレベルにまで輸送活性は低下する．この ようなサイクル形成による糖輸送活性調節は，最近糖輸 送担体に対する抗体を用いた実験でも証明されてい $ろ^{53 \text {. 54) }}$ (Table 1). 注目すべき点は適応調節と違い夕 ンパク合成系が全く関与していないことである (Fig. 7).

インスリンによる糖輸送活性促進作用の細胞内シグナ ルが何であるかということは非常に興味のあるところで ある. 現在，そのシグナルとして考えられているものと しては, (1)細胞内 cAMP 濃度 ${ }^{1)}$ (2)細胞内 $\left[\mathrm{Ca}^{2+}\right]$ の変 動 ${ }^{1,55,56)}$ (3)細胞内 $\left[\mathrm{Mg}^{2+}\right]$ の変動 ${ }^{57,58)}$ (4)細胞内了 ルカリ化 ${ }^{59)}$ (5)細胞膜に存在する $\mathrm{Ca}^{2+}$-ATPase 活性変 化 $^{60)}$ (6) C-kinase の活性化 ${ }^{61,62)}$ (7)インスリン受容体 のリン酸化 ${ }^{63}$ があげられている. (1)(2)(4)については現 在否定的な報告がみられるが64-67)，(5)については追試 がなされていない，(7にについては最近，インスリン受容 体のリン酸化と糖輸送活性との相関性について, 受容体
のアミノ酸残基置換によりリン酸化され得ない受容体を 細胞膜に組み込んだ実験より，インスリン受容体のリン 酸化がインスリン作用に必須であることを証明した報 ${ }^{\text {告 }}{ }^{68)}$ がある. さらに, 自己リン酸化した後のインスリ ン受容体のチロシンキナーゼの活性化がインスリン作用 に必須であるとの報告 ${ }^{69.70)}$ もある。このような報告と は逆に Forsayeth ら ${ }^{71)}$ はヒトインスリン受容体に対す るモノクロナル抗体がインスリン受容体のチロシンキ ナーゼを活性化せずに糖輸送活性を上昇させた実験結果 を得ている，もしリン酸化が必須だとして，リン酸化後 の変化，すなわち受容体がリン酸化された後，チロシン キナーゼの活性の上昇がじのようにして糖輸送担体の細 胞膜への転移をうながすのかは不明であり, 今後の課題 である. 最近, C-kinase が赤血球 ${ }^{72)}$, 3T3-L1 脂肪 細胞 ${ }^{73}$ の糖輸送担体をリン酸化することが判明した。

しかし, 糖輸送活性と輸送担体のリン酸化との相関性に ついては明らかでない，同じ $3 \mathrm{~T} 3-\mathrm{L} 1$ 脂肪細胞において インスリンは糖輸送担体をリン酸化しなかった ${ }^{71)}$.

インスリン受容体および糖輸送系が細胞膜に存在する ことが証明されているにもかかわらず, 肝細胞 ${ }^{74)}$, 脳 神経細胞 $^{75)}$, 胎盤 ${ }^{76)}$ においては, インスリンによる糖 輸送促進効果がみられない，その原因は不明であるが, 

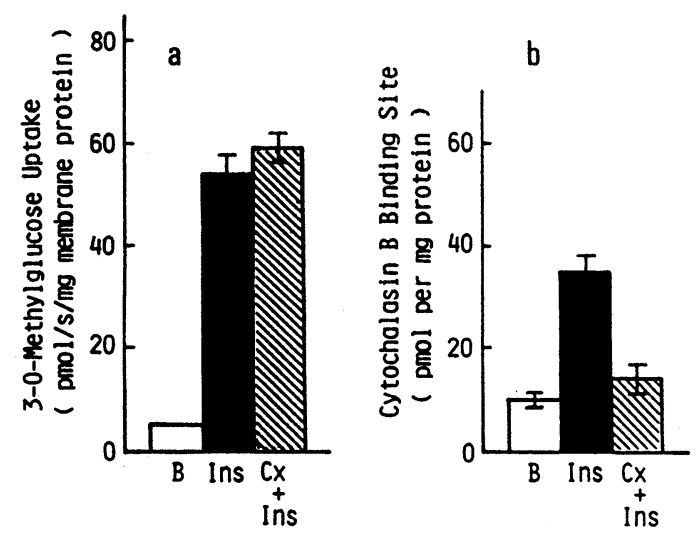

Fig. 8 ラット脂肪細胞膜小胞における 3-0-メチルグ ルコース取り込み活性とサイトカラシンB結合 活性におよぼすインスリンとシクロヘキシミド の影響.

(文献 80 の Fig. 1 と Table 2 より作製)

$\mathrm{B}$, Basal. Cx, シクロヘキシミド $(10 \mu \mathrm{g} / \mathrm{ml})$ Ins, インスリン (7 $\mathrm{nM})$

a) 3-0-メチルグルコース取り込み量

b) サイトカラシンB結合活性

これらインスリン非感受性細胞とインスリン感受性細胞 を比較検討することにより, インスリンによる糖輸送促 進機構を解明する手がかりが得られるかもしれない.

3 -3 糖輸送担体の修飾（活性化, 不活性化）によ る調節

前述のインスリンによるリサイクリング説は現在広 く認められているが，この説で充分説明できない点が観 察されている. それはインスリンによって促進される糖 輸送活性の上昇の倍率と, 転移されて増加する細胞膜の 糖輸送担体の増加倍率之の間に解離があることである. 最近, 赤血球 ${ }^{77}$, 脂肪細胞 ${ }^{78,79)}$ を用いて詳細に糖輸 送キネティックスを調べた結果, インスリンが $V_{m a x}$ を 増加させることに加えて, $K_{m}$ 值も減少させることが判 明した.この事実はインスリンが細胞膜の担体の数を増 加させると同時に輸送担体タンパク質の構造をも変化さ せることを意味する.

Baly ら ${ }^{80)}$ はインスリン効果に対する $\mathrm{Cx}$ の影響につ いて調べた結果, ラット脂肪細胞に Cx を作用させた 後, インスリンを作用させると, 3-OMG の取り込み能 は $\mathrm{Cx}$ 非処理群と $\mathrm{Cx}$ 処理群との間に有意差なく上昇す ることを示した. しかし, 細胞膜の糖輸送担体数をサイ トカラシン B 結合法, および抗体（イムノブロッティン グ法）で調べると, インスリン単独群に比し, $\mathrm{Cx} /$ イン
スリン群の方が少なかった. すなわち糖輸送担体の量と 輸送活性との間に解離がみられた (Fig. 8).この結果よ り, 彼らはインスリンが糖輸送担体を直接修飾して活性 化する可能性を考えている. 一方, カテコールアミン, グルカゴン, ACTH など脂質分解ホルモンは, アデノ シン非存在下（細胞外アデノシンはこれらのホルモン作 用を阻害するためアデノシンデアミナーゼによって除 く）において, インスリンによる糖輸送活性の上昇を阻 害する事実がある81). イソプロテレノールのインスリ ン効果に対する阻害機構について, Joost ら ${ }^{82)}$ は, 輸 送活性の低下に見合う細胞膜糖輸送担体数の減少がない ことより,この阻害作用は細胞膜に存在する輸送担体を 直接不活性化にすることによると述べている (Fig. 7).

糖適店調節に対するタンパク合成系の関与を前述した が, Franch ら ${ }^{83)}$ は腫瘍性肺線維芽細胞を用い, 糖飢 餓効果 (up regulation) に対して Cx が無効であったこ とより, 糖輸送担体が直接活性化されることを推測して いる.

以上, 糖輸送担体が直接活性化, 不活性化されると思 われる事実を述べたが，担体そのものが直接修飾されて いるとの直接証拠はまだ得られてない.

\section{$3 ・ 4$ 細胞膜の脂質組成変化による調節}

糖輸送調節はその担体の数および担体自身の修飾に よって行われることは述べた. さらに, 糖輸送活性は担 体周囲の細胞膜脂質変化によっても変化し得る. 細菌を 用いた実験系では細胞膜脂質組成の変化に伴う膜流動性 の変化之物質輸送活性の変化との相関関係についての研 究は多くみられる. 動物細胞ではこの分野の研究は少な い. Melchior ら ${ }^{84)}$ は脂肪細胞より糖輸送担体を分離 し, リン脂質リポソームに再構成した後, 膜の流動性と 輸送活性とを測定した. その結果, 膜の流動性と糖輸送 活性との間に相関性のあることをみいだした. さらに, 同グループは他の実験 ${ }^{85)}$ で, 脂肪細胞より細胞膜小胞 を調製し, 流動性を増す不飽和脂肪酸を細胞膜小胞に組 み込むと, 糖輸送活性は上昇するがインスリンによる最 大活性の増加は影響されず, 逆に流動性を減少させる飽 和脂肪酸を組み込むと, 元々の糖輸送活性には変化がみ られず，インスリンによって促進されるべき輸送活性が 抑制される結果を得ている. 同様に, 細胞膜の脂肪酸, リン脂質, コレステロールなどの脂質組成変化が糖輸送 活性を変化させることが他にも観察されている ${ }^{86-89)}$.

このように, 糖輸送担体を取りまく脂質組成により輸 送活性は変化するが, はたして生理的にごの程度細胞膜 
脂質が糖輸送の調節に㗢いているか，また糖輸送担体に 特異的な脂質要求性があるのかは明らかでない.

\section{4. おわりに}

糖輸送調節機構を 4 分類して述べたが, それぞれ単独 の機構で調節を行う場合と 2 種類以上の機構が共同して 調節する場合とが考えられる，例えば，グルココルチコ イドは正常な糖輸送活性を低下させるし，インスリンに よる促進効果も阻害する ${ }^{90)}$ 。このグルココルチコイド の作用はアクチノマイシン D, Cx により阻害されるこ とより mRNA，タンパク質合成系が関与することが判 明している ${ }^{91)}$. さらに cyt B 結合活性の測定より, グ ルココルチコイド処理脂肪細胞全体の糖輸送担体数には 変化がなく, 細胞膜に存在する担体の数のみが減少して いることがわかった ${ }^{92)}$. このことはグルココルチコイ ドによって誘導されるタンパク質がリサイクリングのス テップのうち, 細胞内プールから細胞膜への輸送担体の 転移を阻害するか, あるいは逆のステップを促進させて いる可能性がある9 ${ }^{33)}$ (Fig. 7).さらにグルココルチコ イドは脂質代謝を変化させることが知られており ${ }^{94)}$,

膜の流動性に变化を与えて糖輸送活性を低下させる可能 性も否定できない. ある一種類の調節物質が細胞の種類 によって異なる糖輸送調節機構によりその作用を示す場 合がある，例えば，前述の腫瘍プロモーターの糖輸送活 性促進作用は, $\mathrm{CEF}^{49)}$, Balb/c 3T3 細胞 ${ }^{95)}$ ではその 作用発現に時間を要し, タンパク質合成阻害剂により阻 害される. 一方, Hela 細胞 ${ }^{96)}$, Swiss 3T3 細胞 ${ }^{92)}$ に おいては, 腫瘍プロモーターは短時間で作用し, タンパ ク質合成阻害剤により阻害されず，インスリンと同様の 機構で糖輸送活性を上昇させると考えられている ${ }^{977}$. このように細胞によって反応性が違うことは非常に興味 のあるところだが, その詳細は不明である.

以上, 現在判明している糖輸送系の調節機構について 述べたが, 依然として不明な点が多く存在する. 最近七 卜肝腫瘍細胞 ${ }^{98)}$, ラット脳 ${ }^{99)}$ の糖輸送担体の一次構造 が cDNA から求められ, また細胞内プロセッシングも 徐々に解明されつつあり100-102), 今後この分野におけ る発展が期待される.

\section{引用文献}

1) A. Carruthers : Prog. Biophys. Molec. Biol., 43, 33-69 (1984)

2) T.J.Wheeler, P.C. Hinkle : Ann. Rev. Physiol., 47, 503-517 (1985)
3) G. Semenza, M. Kessler, M. Hosang, J. Weber, U. Schmidt : Biochim. Biophys. Acta, 779, 343379 (1984)

4) R. Kinne, M.E.M. Da Cruz, J.T. Lin : Current Topics in Membrane and Transport, 20, 245258 (1984)

5）武居能樹 : 代謝, 23, 395-403 (1986)

6) 山田一夫 : 生化学, 58, 34-40 (1986)

7) R.F. Kletzien, J.F. Perdue : J. Biol. Chem., 249, 3375-3382 (1974)

8) M.J. Weber : J. Biol. Chem., 248, 2978-2983 (1973)

9) R.J. Gay, R. Hilf : J. Cell. Physiol., 102, 155174 (1980)

10) R.F. Kletzien, J.F. Perdue : J. Biol. Chem., 249, 3366-3374 (1974)

11) J. Hochstadt, D.C. Quinlan, R.L. Rader, C. Li, D. Dowd : Methods in Membrane Biology., 5, 117-162 (1975)

12）西野輔翼，乾 賢一：蛋白質・核酸・酵素， 26，881895 (1981)

13) M. Kasahara, P.C. Hinkle : J. Biol. Chem., 253, 7384-7390 (1977)

14) G.D. Eytan : Biochim. Biophys. Acta, 694, 185$202(1982)$

15) D.W. Salter, M.J. Weber : J. Biol. Chem., 254, 3554-3561 (1979)

16) J.E. Pessin, L.G. Tillotson, K. Yamada, W. Gitomer, C. Carter-Su, R. Mora, K.J. Isselbacher, M.P. Czech : Proc. Natl. Acad. Sci. USA, 79, 2286-2290 (1982)

17) M.N. Jones, J.K. Nickson : Biohcem. Biophys. Acta, 650, 1-20 (1981)

18) G.E. Lienhard, F.R. Gorga, J.E. Orasky, M. A. Zoccoli : Biochemistry, 16, 4921-4926 (1977)

19) E.R. Batt, R.E. Abbott, D. Schachter : J. Biol. Chem., 251, 7184-7190 (1976)

20) M.F. Shanahan : J. Biol. Chem., 257, 7290-7293 (1982)

21) C. Carter-Su, J.E. Pessin, R. Mora, W. Gitomer, M.P. Czech : J. Biol. Chem., 257, 54195425 (1982)

22) R.E. Mullins, R.G. Langdon : Biochemistry, 19, 1199-1205 (1980)

23) W.D. Rees, J. Gliemann, G.D. Holman : Biochem. J., 241, 857-862 (1987)

24) T.M. Weber, A. Eichholz : Biochim. Biophys. Acta, 812, 503-511 (1985)

25) J.M. May, R. Horuk, J.M. Olefsky : Molec. Cell. Endocrinol., 49, 181-188 (1987)

26) M.F. Shanahan, D.P. Morris, B.M. Edwards : J. Biol. Chem., 262, 5978-5984 (1987)

27) S.A. Baldwin, G.E. Lienhard : Biochem. Biophys. Res. Commun., 94, 1401-1408 (1980)

28) D.C. Sogin, P.C. Hinkle : Proc. Natl. Acad. Sci. USA, 77, 5725-5729 (1980) 
29) M. Kasahara, K. Inui, M. Takano, R. Hori : Biochem. Biophys. Res. Commun., 132, 490496 (1985)

30) W.J. Allard, G.E. Lienhard : J. Biol. Chem., 260, 8668-8675 (1985)

31) C. Chen, T. Kurokawa, S. Shaw, L.G. Tillotson, S. Kalled, K.J. Isselbacher : Proc. Natl. Acad. Sci. USA, 83, 2652-2656 (1986)

32) S. Venuta, H. Rubin : Proc. Natl. Acad. Sci. USA, 70, 653-657 (1973)

33) K. Inui, D.E. Moller, L.G. Tillotson, K.J. Isselbacher : Proc. Natl. Acad. Sci. USA, 76, 39723976 (1979)

34) K. Inui, L.G. Tillotson, K.J. Isselbacher : Biochim. Biophys. Acta, 598, 616-627 (1980)

35) D.W. Salter, S.A. Baldwin, G.E. Lienhard, M.J. Weber : Proc. Natl. Acad. Sci. USA, 79, 1540-1544 (1982)

36) M.K. White, M.E. Bramwell, H. Harris : Nature, 294, 232-235 (1981)

37) M.A. Gray, M.H. James, J.C. Booth, C.A. Pasternak : Arch. Virol., 87, 37-48 (1986)

38) S. Kawai, H. Hanafusa : Virology, 46, 470-479 (1971)

39) J.S. Flier, M.M. Mueckler, P. Usher, H.F. Lodish : Science, 235, 1492-1495 (1987)

40) R. Martineau. M. Kohlbacher, S.N. Shaw, H. Amos : Proc. Natl. Acad. Sci. USA, 69, 34073411 (1972)

41) C.W. Christopher, W.W. Colby, D. Ullrey : J. Cell. Physiol., 89, 683-692 (1976)

42) R.F. Kletzien, J.F. Perdue : J. Biol. Chem., 250, 593-600 (1975)

43) R.J. Germinario, H. Rockman, M. Oliveira, S. Manuel, M. Taylor : J. Cell. Physiol., 112, 367-372 (1982)

44) L.G. Tillotson, K. Yamada, K.J. Isselbacher : Federation Proc., 43, 2262-2264 (1984)

45) H. Amos, T.A. Musliner, H. Asdonrian : J. Supramol. Struct., 7, 499-513 (1977)

46) K. Yamada, L.G. Tillotson, K.J. Isselbacher : J. Biol. Chem., 258, 9786-9792 (1983)

47) H.C. Haspel, E.W. Wilk, M.J. Birnbaum, S. W. Cushman, O.M. Rosen : J. Biol. Chem., 261, 6778-6789 (1986)

48) K. Yamada, L.G. Tillotson, K.J. Isselbacher : 未発表

49) K. Yamada, L.G. Tillotson, K.J. Isselbacher : J. Cell. Physiol., 127, 211-215 (1986)

50) K. Suzuki, T. Kono : Proc. Natl. Acad. Sci. USA, 77, 2542-2545 (1980)

51) S.W. Cushman, L.J. Wardzala : J. Biol. Chem., 255, 4758-4762 (1980)

52) T. Kono, K. Suzuki, L.E. Dansey, F.W. Robinson, T.L. Blevins : J. Biol. Chem., 256, 64006407 (1981)
53) T.J. Wheeler, I.A. Simpson, D.C. Sogin, P. C. Hinkle, S.W. Cushman : Biochem. Biophys. Res. Commun., 105, 89-95 (1982)

54) O. Ezaki, M. Kasuga, Y. Akanuma, K. Takata, H. Hirano, Y.F. Yamaguchi, M. Kasahara : J. Biol. Chem., 261, 3295-3305 (1986)

55) T. Clausen : Cell Calcium, 1, 311-325 (1980)

56) Y. Shecter : Proc. Natl. Acad. Sci. USA, 81, 327-331 (1984)

57) J. Eckel, G. Pandalis, H. Reinauer : Biochem. J., 212, 385-392 (1983)

58) K. Kitagawa, H. Nishino, A. Iwashima : $E x$ perimentia, 43, 323-324 (1987)

59) K. Kitagawa, Y. Ogiso, H. Nishino, A. Iwashima : Cell Structure and function, 12, 115119 (1987)

60) E. Schoenle, E.R. Froesch : FEBS Letters, 123, 219-221, (1981)

61) R.L. Christensen, D.L. Shade, C.B. Graves, J.M. McDonald, : Int. J. Biochem., 19, 259-265 (1987)

62) D.R. Cooper, T.S. Konda, M.L. Standaert, J. S. Davis, R.J. Pollet, R.V. Farese : J. Biol. Chem., 262, 3633-3639 (1987)

63) R.A. Kohanski, S.C. Frost, M.D. Lane : J. Biol. Chem., 261, 12272-12281 (1986)

64) V.R. Lavis, R. Davenport, P. Pontier, W.J. Thompson, S.J. Strada : J. Cell. Physiol., 112, 373-375 (1982)

65) M. Kuroda, R.C. Honnor, S.W. Cushman, C. Londos, I.A. Simpson : J. Biol. Chem., 262, 245-253 (1987)

66) J.Y. Cheng, J.M. Constantine, J.V. Bonventre : Am. J. Physiol., 252, C163-C172 (1987)

67) A. Klip, T. Ramlal, E.J. Cragoe Jr. : Am. J. Physiol., 250, C720-C728 (1986)

68) L. Ellis, E. Clauser, D.O. Morgan, M. Edery, R.A. Roth, W.J. Rutter : Cell, 45, 721-732 (1986)

69) Y. Ebina, E. Araki, M. Taira, F. Shimada, M. Mori, C.S. Craik, K. Siddle, S.B. Pierce, R.A. Roth, W.J. Rutter : Proc. Natl. Acad. Sci. USA, 84, 704-708 (1987)

70) C.K. Chou, T.J. Dull, D.S. Russell, R. Gherzi, D. Lebwohl, A. Ullrich, O. M. Rosen : J.Biol. Chem., 262, 1842-1847 (1987)

71) J.R. Forsayeth, J.F. Caro, M.K. Sinha, B.A. Maddux, I.D. Goldfine : Proc. Natl. Acad. Sci. USA, 84, 3448-3451 (1987)

72) L.A. Witters, C.A. Vater, G.E. Lienhard : Nature, 315, 777-778 (1985)

73) E.M. Gibbs, W.J. Allard, G.E. Lienhard : J. Biol. Chem., 261, 16597-16603 (1986)

74) T.P. Ciaraldi, R. Horuk, S. Matthaei :Biochem. J., 240, 115-123 (1986)

75) F.K. Gorus, E.L. Hooghe-Peters, D.G. Pipe- 
leers : J. Cell. Physiol., 121, 45-50 (1984)

76) P. Trauman, H.C. Ford : Biochim. Biophys. Acta, 779, 139-160 (1984)

77) M.L. Dustin, G. Jacobson, S.W. Peterson : J. Biol. Chem., 259, 13660-13663 (1984)

78) R.R. Whitesell, N.A. Abumrad : J. Biol. Chem., 261, 15090-15096 (1986)

79) N. Toyoda, J.E. Flanagan, T. Kono : J. Biol. Chem., 262, 2737-2745 (1987)

80) D.L. Baly, R. Horuk : J. Biol. Chem., 262, 21-24 (1987)

81) A. Green : FEBS Letters, 152, 261-264 (1983)

82) H.G. Joost, T.M. Weber, S.W. Cushman, I. A. Simpson : J. Biol. Chem., 261, 10033-10036 (1986)

83) A. Franchi, P. Silvestre, J. Pouyssegur : Biochem. Biolphys. Res. Commun., 85, 15261534 (1978)

84) D.L. Melchior, M.P. Czech : J. Biol. Chem., 245, 8744-8747 (1979)

85) P.F. Pilch, P.A. Thompson, M.P. Czech : Proc. Natl. Acad. Sci. USA, 77, 915-918 (1980)

86) S.J. Masiak, P.G. LeFevre : Arch. Biochem. Biophys., 162, 442-447 (1974)

87) I. Yuli, W. Wilbrandt, M. Shinitzky :Biochemistry, 20, 4250-4256 (1981)

88) T. Fujii, A. Tamura, H. Fujii, I. Miwa, J. Okuda : Biochem. Int., 12, 873-879 (1986)

89) D.H. Nelson, D.K. Murray : Biochem. Biophys. Res. Commun., 138, 463-467 (1986)

90) N. Watanabe, M. Kobayashi, H. Maegawa, O.
Ishibashi, Y. Takata, Y. Shigeta : J. Biochem., 96, 1893-1902 (1984)

91) C. Carter-Su, K. Okamoto : Am. J. Physiol., 248, E215-E223 (1985)

92) C. Carter-Su, K. Okamoto : J. Biol. Chem., 260, 11091-11098 (1985)

93) C. Carter-Su, K. Okamoto : Am. J. Physiol., 252, E441-E453 (1987)

94) D.H. Nelson, D.K. Murray : Proc. Natl. Acad. Sci. USA, 79, 6690-6692 (1982)

95) T.G. O’Brien : J. Cell. Physiol., 110, 63-71 (1982)

96) L.S. Lee, I.B. Weinstein : J. Cell. Physiol., 99, 451-460 (1979)

97) K. Kitagawa, H. Nishino, A. Iwashima : Biochem. Biophys. Res. Commun., 128, 1303-1309 (1985)

98) M. Mueckler, C. Caruso, S.A. Baldwin, M. Panico, I. Blench, H. R. Morris, W. Jeffrey, G.E. Lienhard, H.F. Lodish : Science, 229, 941-945 (1985)

99) M.J. Birnbaum, H.C. Hapsel, O.M. Rosen : Proc. Natl. Acad. Sci. USA, 83, 5784-5788 (1986)

100)H.C. Haspel, M.J. Birnbaum, E.W. Wilk, O. M. Rosen : J. Biol. Chem., 260, 7219-7225 (1985)

101) M. Mueckler, H.F. Lodish : Cell, 44, 629-637 (1986)

102) M. Mueckler, H.F. Lodish : Nature, 322, 549$552(1986)$

\section{膜 物 理 化 学}

中垣 正幸 : 星薬科大学教授 ; 京都大学名誉教授

1987, A 5 判 200 ページ, 定価 2,800 円, 喜多見書房, 東京

日本膜学会が約 10 年前に発足し, 今日まで生体膜と 人工膜の分野の交流を計り, お互いの研究を理解し，そ れによって相互の研究の発属を計ろうとして活動してき たその基礎になる考え方は,その基本となる物理化学は, 共通であるという信念である. その膜学会の会長を発足 以来勤めてこられた中垣先生が, 京都大学を定年退官さ れるに当たり，長年続けてこられた，膜に関するご自分 の研究に基づきつつ，その物理化学の体系をまとめられ たのが本書である.

その内容は以下の 12 章からなっている. 1) 膜とその 機能, 2) 成膜仕事, 3) 脂質単分子膜, 4) 2 分子膜の安 定性之非対称性, 5) 界面反応化学, 6) 物質輸送の速度 論と熱力学, 7) 膜輸送現象の基礎, 8) 溶質の拡散と膜 透過，9）電解質の拡散, 10) 膜電位, 11) 電解質の荷電 膜透過, 12) 非対称膜の膜電位と膜透過

このようにその内容は, まず歴史的発展の順にコロイ ド化学の基礎から始まり, 最近再び大きく注目されるよ うになった単分子膜, 2 分子膜, LB 膜, の成果を紹介 し, 次に, 膜透過の輸送現象に基礎となる不可逆過程の 熱力学から輸送方程式について解説されている. またこ こに現われる輸送係数, 例えば拡散係数などについては, 速度論に基づく透過機構と関連づける必要があり, また これは膜電位とも関係する。これらについてていねいに 解説されている.

現在膜に関する研究は, 各方面で注目され, 研究開発 が行われているが, その基礎になるのは物理化学であり, 物性論であることは言うまでもない. 膜の研究は先を急 ぐ余り, 膜探しに追われて, 基礎を振り返ることを忘れ てはならない. 本書の一読を是非お萀めしたい。

（東京大学工学部 木村尚史） 